Arq. Bras. Med. Vet. Zootec., v.67, n.4, p.979-983, 2015

\title{
Successful use of autogenous bone graft for the treatment of a radius-ulna nonunion in an amputee dog
}

\author{
[Uso de enxerto ósseo autógeno no tratamento de uma não união óssea em um \\ radioulna de um canino amputado] \\ B.W. Minto, T.C. Prada, P.V.T. Marinho, C.C. Zani, M.P.D. Menezes \\ Universidade Estadual Paulista - Unesp-Jaboticabal - Jaboticabal, SP
}

\begin{abstract}
Fracture nonunions represent important complications in orthopedic surgeries. Nonunion repairs or bone defects are surgically challenging. Our aim was to describe a nonunion case, which was repaired with rapid bone recovery. An 8-month-old male mixed breed dog that has been previously operated was presented to the Veterinary Medical Teaching Hospital of São Paulo State University, with a right radiusulna nonunion and an amputated contralateral forelimb. A cancellous bone graft was collected from a partially amputated limb, in order to correct the nonunion, and used in association with a locking plate. After four weeks, the bone graft had been incorporated into the original bone. Clinical union with good weight bearing was achieved after eight weeks.
\end{abstract}

Keywords: fracture, complication, orthopaedics, surgery, humerus

\section{RESUMO}

As não uniões ósseas representam uma importante complicação nas cirurgias ortopédicas. Não uniões ósseas ou defeitos ósseos são um desafio na cirurgia. O objetivo do presente trabalho foi descrever um caso de não união óssea, que foi reparada de forma rápida. Um cão SRD de oito meses, macho, que havia sido operado previamente, deu entrada no Hospital Veterinário da Unesp - Jaboticabal com uma não união óssea em radioulna e o membro contralateral amputado. Um enxerto ósseo autógeno foi coletado do coto do membro contralateral amputado e utilizado junto a uma placa óssea bloqueada para o tratamento. Após quatro semanas, o enxerto ósseo estava incorporado ao osso original. A união clínica e o retorno normal à função foram alcançados após oito semanas.

Palavras-chave: fratura, complicação, ortopedia, cirurgia, úmero

\section{INTRODUCTION}

Fracture nonunions usually occur due to instability, infection, or poor blood supply. Depending on the location, nonunions could affect nearly $60 \%$ of the fracture cases (Piermattei et al., 2006). Fractures of the radius and ulna present a higher risk for delayed union or nonunion, especially in small breed dogs (Piras et al., 2011).

Repairing nonunion or bone defects is surgically challenging. Surgeons, instead, should consider advantages and disadvantages of each alternative for a specific clinical situation, and select the material with the lowest overall cost and morbidity, and highest probability of success (Byung-jun et al., 2008).

Autogenous bone is still considered the gold standard for most applications as it is vascularized and integrates with surrounding bones, thus minimizing the risk of infection, displacement or break-down. Limitations include extra operative time because of graft collection, donor site morbidity, graft resorption, molding challenges, and limited availability (Roger, 2012).

Recebido em 8 de outubro de 2014 
The use of autogenous cancellous bone grafting in areas of incomplete ossification has been proposed in order to optimize bone formation and remodeling by providing the necessary trabeculae for bone conduction and osteoprogenitor cells, as well as cytokines and growth factors for osteoinduction and osteogenesis (Fitzpatrick et al., 2009).

Researchers studying bone graft collection in humans report a morbidity rate of $25 \%$ with complications that range from increased surgical time to fractures, pain, bleeding, and limited graft availability. Although the true complication rate has not been reported in veterinary medicine, isolated complications have been reported from the use of cancellous autografting in small animals (Bisgard et al., 2011). AO principles support the combination of graft and rigid internal fixation for the promotion of bone union (Fitzpatrick et al., 2009).

In both human and veterinary patients, locking plates are commonly used for the treatment of long bone fractures (Greiwe, 2007; Irubetagoyena et al., 2013). They are designed to limit bone contact with the plate, which minimizes bone vasculature damage (Frigg, 2001).

Our aim is to describe an uncommon use of autogenous bone graft combined with a locking plate (LP) for the treatment of no weight bearing attribute to nonunion radius-ulna fracture in a $\mathrm{dog}$, and report the short term clinical outcomes.

\section{CLINICAL REPORT}

An 8-month-old male mixed breed dog, body weight $8.3 \mathrm{~kg}$, that has been previously operated for another surgeon was presented to the Veterinary Teaching Hospital of the São Paulo State University, presenting a right radius-ulna nonunion and an amputated contralateral forelimb.

Upon physical examination the dog did not support the affected member on the floor. In addition, there was no motion on the elbow joint. The radiographic examination in a cranio-caudal projection showed an intramedullary pin between the distal radius and proximal humerus and a large bone gap on the radius (Figure 1a,b). A medio-lateral radiography was performed from the amputated forelimb for planning a possible bone graft (Figure 2).

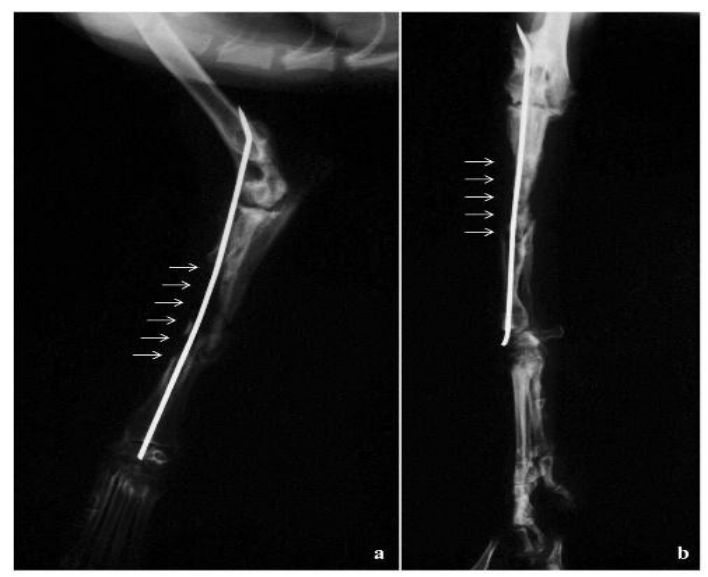

Figure 1. a: Pre-operative cranio-caudal radiographic view from radio-ulna nonunion. See a large bone gap (arrows) in the radius. b: Preoperative medio-lateral radiographic view from the radio-ulna nonunion. See a large bone gap (arrows) in radius.

The surgical procedure was performed one week after diagnosis. Analgesia was provided by tramadol hydrochloride [Tramal Retard: Pfzer, Guarulhos, São Paulo, Brazil] (2mg/kg TID OS) until surgical procedure.

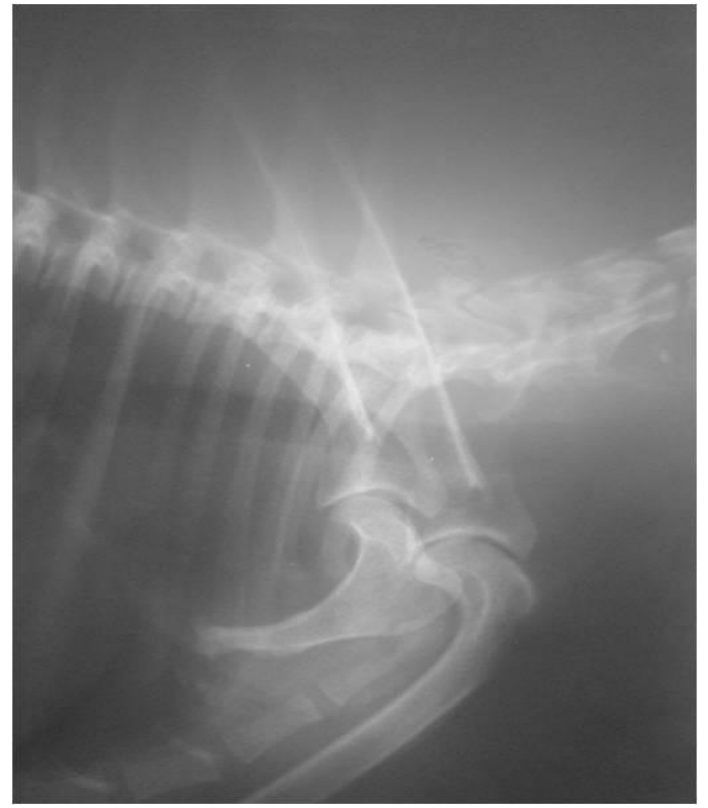

Figure 2. Medio-lateral radiographic view of the left forelimb of the dog, amputated at the proximal humerus level. 
On the day of the surgery, morphine sulphate [Dimorf: Cristária, Itapira, São Paulo, Brazil] $(0.5 \mathrm{mg} / \mathrm{kg} \quad \mathrm{IM})$ was administered as premedication. Induction of anesthesia was performed with propofol [Propovan: Cristália, Itapira, São Paulo, Brazil] (5mg/kg IV) and general anesthesia was maintained with isoflurano [Isofurine: Cristália, Itapira, São Paulo, Brazil] diluted in $100 \%$ of oxygen under spontaneous ventilation. After intubation, cefazolin [Cefazolina: B-MS, São Paulo, São Paulo, Brazil] (30mg/kg IV) was administered.

Under sterile conditions, the contralateral limb (left) was assessed for removal of the proximal humeral fragment (cancellous bone graft). The fragment was transected and shaped (Figure 3) with an oscillating saw. This bone was kept in a $0.9 \%$ saline solution while the fractured limb was analyzed. A craniomedial approach was performed. The periosteum was elevated only enough to fit the plate directly on the bone. A ten-hole 2.7 LP was contoured and applied to the cranial aspect of the radius. The humeral fragment was placed into the radial defect before fixing the plate from the proximal to distal aspect of the radius (three screws were inserted in the proximal aspect of the radius; two monocortical screws, into the bone graft; and three screws, in the distal radius). After closing the surgical injury, a bandage was used for two weeks. After surgery the animal was treated with enrofloxacina [Baytril: Bayer, São Paulo, São Paulo, Brazil] (5mg/kg BID OS) for ten days, meloxicam [Maxicam: Ourofino, Cravinhos, São Paulo, Brazil] (0,1 mg/kg SID OS) for five days, and tramadol hydrochloride [Tramal Retard: Pfzer, Guarulhos, São Paulo, Brazil] (4 mg/kg TID OS) for seven days. A Robert Jones bandage was applied to the operated limb for 7 days.

The patient was able to partially bear weight after two weeks. No infection or failure of the implant was noted.

Lateral and craniocaudal radiographs of the right antebrachium were performed before and immediately after surgery, as well as after two, four, eight, 12, and 20 weeks of surgery.

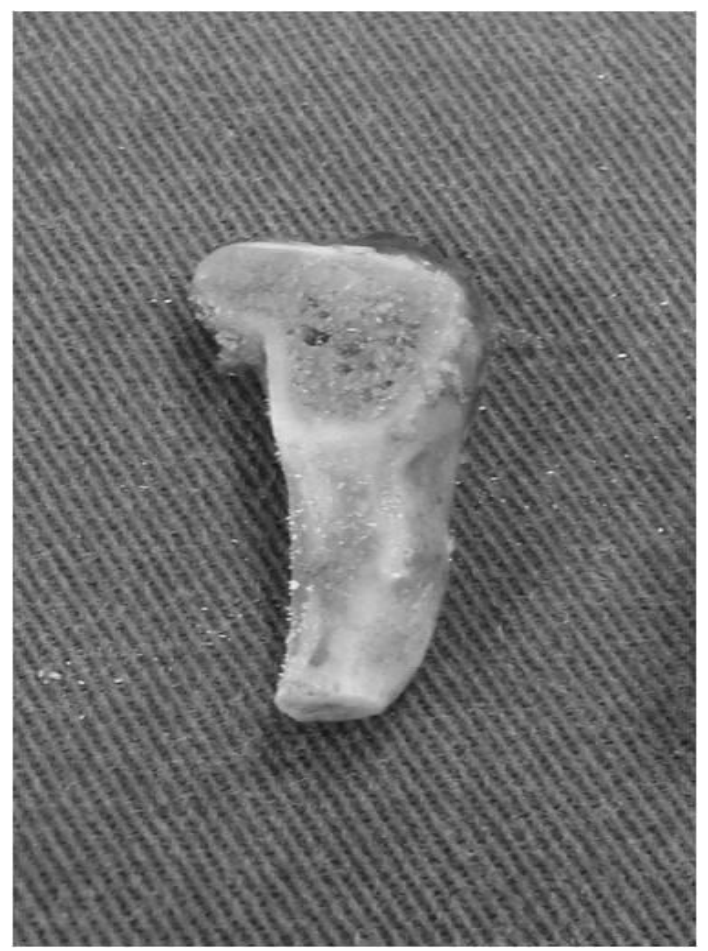

Figure 3. Fragment removed from the proximal humerus and shaped with an oscillating saw.

Immediate postoperative radiograph showed good limb axial alignment and bone graft position between the host bone placed with an LP (Figure 4). Clinical union between autogenous bone graft and host bone was noted after four weeks of surgery. At eight weeks, fracture line was no longer observed on radiographs. Signs of bone remodeling had already been observed by that time. The dog did not receive any specific intervention, and gradually increased controlled leash-based activities for the following four weeks.

After 60 days the two monocortical screws, which were fixed to the graft, were removed.

After six months the dog presented normal weight bearing and quality of life. Remodeling was observed and there were no other significant changes on radiographs (Figure 5).

The study was approved by the Ethics Committee from FCAV- UNESP Jaboticabal under number 23.644/14. 


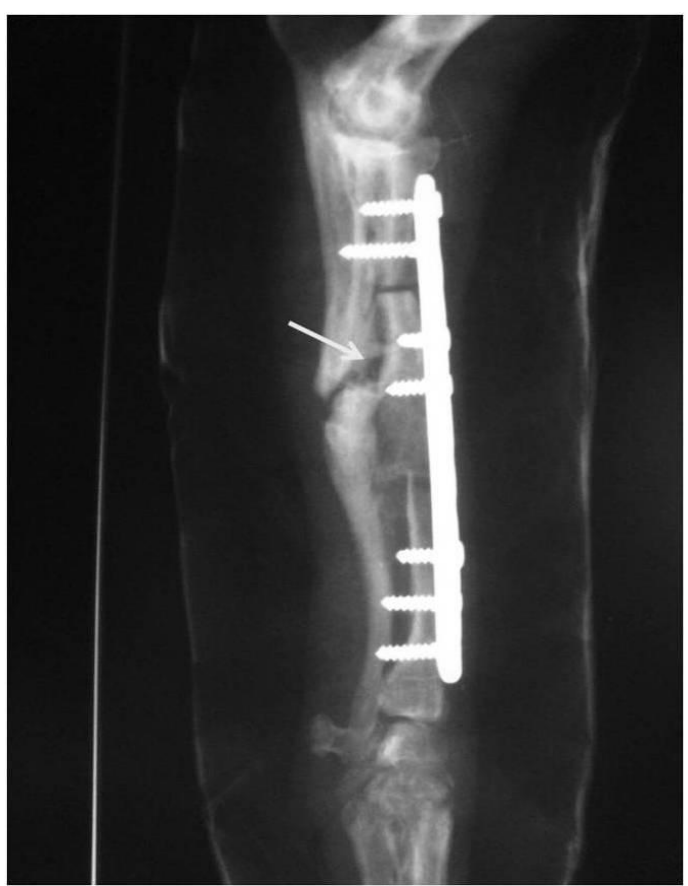

Figure 4. Medio-lateral radiographic view of the right forelimb after osteosynthesis with a locking plate. See bone graft placed into the gap and fixed with two monocortical locking screws (arrow).

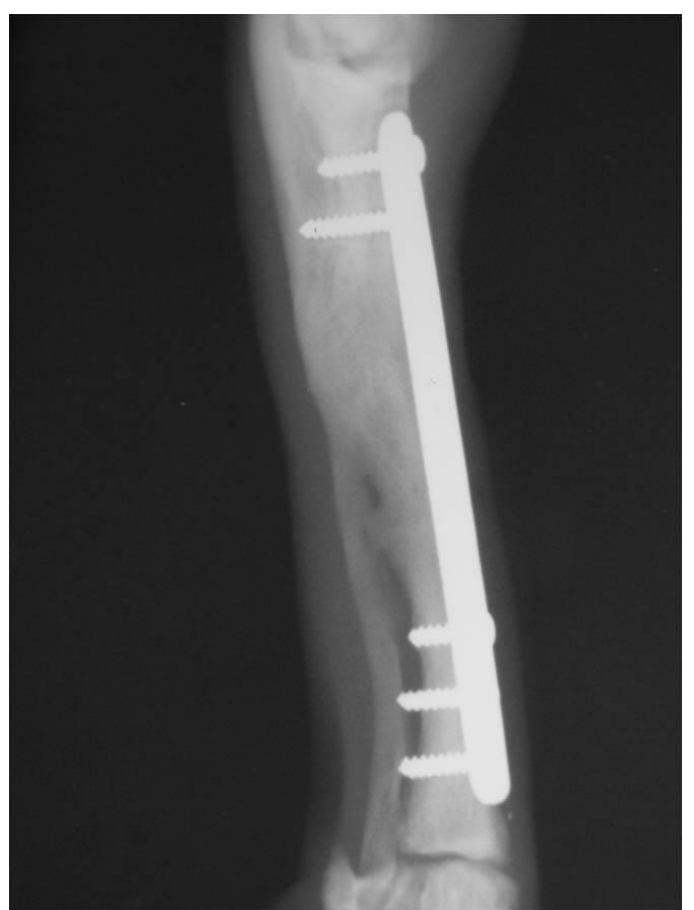

Figure 5. Medio-lateral radiographic view of the right forelimb after osteosynthesis with a locking plate at six months of surgery.

\section{DISCUSSION}

Bone formation with substitute grafts relies on a complex sequence of events that depends on vascular ingrowth, differentiation of osteoprogenitor cells, bone remodeling, and graft resorption, which occur with host bone ingrowth (Byung-jun et al., 2008). Dogs with grafts had significantly higher overall healing scores than those without grafts, regardless of the implants. Therefore, in the case of nonunions, they are used to accelerate bone healing and provide good fracture consolidation (Bisgard et al., 2011).

The main purpose of bone grafting is to hasten osteotomy gap healing, thus relying on osteotomy stabilization by implants for a shorter period of time and, theoretically, minimizing implant-associated complications. Autogenous cancellous bone grafting is considered the best grafting type as it presents osteogenesis, osteoinduction, and osteoconduction properties that reportedly accelerate healing for up to four weeks in some situations. However, graft collection is associated with several potential complications such as fractures, pain, bleeding and increased surgical time (Bisgard et al., 2011). In the present study, these complications, as cited in the literature, have not been observed. Akagi et al. (2013) mentioned the presence of two cases of bacterial infections, out of seven, in a study on autologous bone grafting for repairing a femoral nonunion.

Total cortical grafts have the advantage of withstanding higher strength; however, it is less osteoinductive than the cancellous bone (Nather, 2010). Nevertheless, in our study using corticocancellous bone, healing time was similar to that resulted from cancellous bone.

In our case, only an intramedular pin had been previously used to fix the fracture by another surgeon. Surgical technique errors contribute to $80 \%$ of the post-surgical complication cases, among them, delayed unions or nonunions. Intramedullary pins, when used as primary fixation, do not generate a stable environment for bone consolidation, thereby leading, in most cases, to a nonunion condition. In these situations, axial and torsional strength are not neutralized (Blaeser, 2003). 
Plates, external fixation or interlocking nails are used for maintenance of fracture alignment. Fracture union occurs by direct bone healing when the compression technique is used, and by indirect bone healing with formation of bridging callus followed by osseous remodeling (Hudson, 2009). The LP only has locking holes, with no compression. When the locking screw function is employed, LP works as an internal fixator, and the plate does not require precise adaptation of the plate on the bone surface to provide stable fixation (Hudson, 2009), so minimal damage to periosteal bone may be achieved (Frigg, 2001). LP use has many advantages for bone healing, allowing early consolidation and successful surgical procedure. In general, it takes longer for nonunion cases reach satisfactory results (Greiwe, 2007).

For the collection of autogenous bone grafts, animals have many potential donor sites. Some factors that influence site collection are length and diameter of the required dowel, contour of the cis cortex cortical bone, and patient positioning. The most used sites are the proximal humerus and tíbia (Fitzpatrick et al., 2009). As the contralateral limb amputation was partially performed, we had the opportunity to collect the graft from this member, thus arousing interest for future preservation, when possible, of fragments from amputated limbs for possible grafting use if necessary.

We concluded that the use of this uncommon autogenous corticocancellous bone combined with LP was an effective and appropriate treatment of no weight bearing attribute to nonunion radius-ulna fracture. This technique led to consistent resolution of consolidation and bony union according to the observed on radiographs. No major complications were noted during either short or long term follow-up.

\section{REFERENCES}

AKAGI, H.; OCHI, H.; KANNNO, N. et al. Clinical efficacy of autogenous cancellous bone and fibroblast growth factor 2 combined with frozen allografts in femoral nonunion fractures. Vet. Comp. Orthop. Traumatol., v.26, p.123-129, 2013.
BISGARD, S.K.; BARNHART, M.D.; SHIROMA, J.T. et al. The effect of cancellous autograft and novel plate design on radiographic healing and postoperative complications in tibial tuberosity advancement for cranial cruciate-deficient canine stifles. Vet. Surg., v.40, p.402-407, 2011.

BLAESER, L.L. Treatment of biologically inactive nonunions by a limited en bloc ostectomy and compression plate fixation: a review of 17 cases. Vet. Surg., v.32, p.91-100, 2003.

BYUNG-JUN, J.; YE-EUN, B.; JI-HEY, L. et al. Implantation of canine umbilical cord blood-derived mesenchymal stem cells mixed with beta-tricalcium phosphate enhances osteogenesis in bone defect model dogs. J. Vet. Sci., v.9, p.387-393, 2008.

FITZPATRICK, N.; SMITH, T.J.; O'RIORDAN, J. et al. Treatment of incomplete ossification of the humeral condyle with autogenous bone grafting techniques. Vet. Surg., v.38, p.173-184, 2009.

FRIGG, R. Locking Compression Plate (LCP) An osteosynthesis plate based on the dynamic compression plate and the point contact fixator (PCFix). Injury, v.32, p.B63-6, 2001.

GREIWE, R.M. Locking plate technology: current concepts. J. Knee. Surg., v.20, p.50-55, 2007.

HUDSON, C.C. Minimally invasive plate osteosynthesis: applications and techniques in dog and cats. Vet. Comp. Orthop. Traumatol., v.22, p.175-182, 2009.

IRUBETAGOYENA, I.; VERSET, M.; PALIERNE, S. et al. Ex vivo cyclic mechanical behaviour of 2.4 $\mathrm{mm}$ locking plates compared with $2.4 \mathrm{~mm}$ limited contact plates in a cadaveric diaphyseal gap model. Vet. Comp. Orthop. Traumatol., v.26, p.1-10, 2013.

NATHER, A. Effect of autologous mesenchymal stem cells on biological healing of allografts in criticalsized tibial defects simulated in adult rabbits. Ann. Acad. Med. Sing., v.39, p.599-606, 2010.

PIERMATTEI, D.L.; FLO, G.L.; DECAMP, C.E. Delayed union and nonunion. In: PIERMATTEI, D.L.; FLO, G.L.; DECAMP, C.E (Eds.). Brinker, Piermattei and Flo's handbook of small animal orthopedics and fracture repair. Philadelphia: Saunders, 2006. p.168176.

PIRAS, L.; CAPPELlARI,, F.; PEIRONE, B.; FERRETTI, A. Treatment of fractures of distal radius and ulna in toy breed dogs with circular external skeletal fixation: a retrospective study. Vet. Comp. Orthop. Traumatol., v.24, p.228-35, 2011.

ROGER, G.F. Autogenous bone graft: basic science and clinical implications. J. Craniofac. Surg., v.23, p.323-7, 2012. 